East African Medical Journal Vol. 84 No. 11 November 2007

PREVALENCE OF PTERYGIUM AND PINGUECULUM AMONG MOTORCYCLISTS IN NIGERIA

C.U. Ukponmwan, MBBS, FMCOph, FWACS, Senior Lecturer/Consultant Ophthalmologist, O.A. Dawodu, MBBS, FMCOph, FWACS, Senior Lecturer/Consultant Ophthalmologist, O. Edema, MBBS, FMCOph, FWACS, Senior Lecturer/ Consultant Ophthalmologist, Department of Ophthalmology, University of Benin Teaching Hospital, P.M.B. 1154, Benin City, Nigeria and O. Okojie, MBBS, FMCPH, Professor/Consultant, Department of Community Health, University of Benin Teaching Hospital, Benin City, Nigeria

Requests for reprints to: Dr. C.U. Ukponmwan, Department of of Ophthalmology, University of Benin Teaching Hospital, P.M.B. 1154, Benin City, Nigeria

\title{
PREVALENCE OF PTERYGIUM AND PINGUECULUM AMONG MOTORCYCLISTS IN NIGERIA
}

\author{
C.U. UKPONMWAN, O.A. DAWODU, O.F. EDEMA and O. OKOJIE
}

\begin{abstract}
Objectives: To find out the prevalence of pingueculum and pterygium among commercial motorcyclists in Benin City, Nigeria and to note any associated or risk factors.

Design: A prospective, cross sectional, case control study.

Setting: A local Government Area (Oredo) and University of Benin Teaching Hospital, Benin City, Nigeria.

Subjects: One hundred and forty four commercial male motorcyclists in motorcycle parks in the local Government area and a control group of 114 male indoor workers.

Main outcome measures: Presence of pterygium or pingueculum.

Results: One hundred and forty four male motorcyclists formed the subjects of this study. The age range was 18 to 65 years with a mean age of $34.9 \pm 8.0$ years. The total number of motorcyclists with pingueculum was 37 with 26 bilateral cases, 63 eyes were involved. The prevalence rate was $25.7 \%$. Pterygium was present in 18 patients including 12 bilateral cases making a total of 30 eyes. The prevalence rate was $12.5 \%$ The total number of indoor workers with pingueculum was 24 and it was present in 46 eyes. The prevalence rate was $21.05 \%$. Pterygium was present in 12 eyes of nine persons in the control group and the prevalence rate was $7.9 \%$. There was no association between the duration of work as a commercial motor cyclist and the presence of a pterygium or a pingueculum. The usage of a hat/cap was found to have a protective effect as motorcyclists who do not wear hats are more likely to develop pingueculum than those who wear them. The use of glasses and hats together was found to be protective against the development of pingueculum and pterygium in this study.

Conclusion: The prevalence rate of $12.5 \%$ of pterygium and $25.7 \%$ of pingueculum in commercial motorcyclists in this study is quite high when compared with that of the controls. The wearing of face caps / hats was found to have a protective effect. They should be educated about the importance of wearing protective goggles and caps/brimmed hats.
\end{abstract}

\section{INTRODUCTION}

Motorcycles are now an important means of transportation in Benin City, Nigeria. The commercial motorcyclists involved work for long durations and they are exposed to sunlight, wind and dust for long periods each day. Ultraviolet radiation has been implicated in the causation of eye diseases such as pingueculum, pterygium, solar keratosis, squamous cell carcinoma, cataract, age related macula degeneration and some eyelid malignancies (1-3). It is the major environmental risk factor in the 
development of pingueculum and pterygium (4-8). Chronic inflammation, corneal microtrauma from exposure to dust and wind have also been implicated in their aetiology(6-8).

The aim of this study was to find out the prevalence of pingueculum and pterygium among commercial motor cyclists in Benin City, Nigeria and to note any associated or risk factors.

\section{MATERIALS AND METHODS}

This cross-sectional study was conducted in Benin City, the capital of Edo State, among commercial motorcyclists. A sample size of 180 was calculated (9) and participants were motorcyclists in selected motor parks using the cluster sampling method. Each motorcycle park was taken as a cluster and all the riders in the selected parks were included in the study. One hundred and forty four commercial motorcyclists from the parks in one of the local government areas (Oredo) in Benin City were the subjects of the study. They comprised $80 \%$ of the estimated sample size of 180 .

The control group was made up of 114 indoor workers and students (males) of the University of Benin and the University of Benin Teaching Hospital.

The ethics committee of the University of Benin Teaching Hospital approved the study. An informed consent was obtained from the subjects before being included in the study. The tool for data collection was a structured questionnaire which was interviewer administered. The questionnaire contained information on the driver's demographic characteristics such as sex, age, occupation, duration of the job, the number of working hours per day, the use of protective clothings (glasses, hats/caps), the presence of any eye problems and previous history of any eye disease.

Eye examination was also conducted on respondents. The eye examination was carried out in the offices at the park. This included visual acuity using the Snellen's chart or the illiterate E chart at 6 metres with or without glasses, pinhole visual acuity test in motorcyclists with less than $6 / 6$ vision. Ocular examination was done with a pen torch and a direct ophthalmoscope. The prescence or absence of a pterygium or pingueculum was noted. Other lesions were also noted. Fundoscopy was done with direct ophthalmoscope and patients with any pathology such as glaucomatous discs were referred to the University of Benin Teaching Hospital for further investigation and treatment. Dilatation was done in some participants with poor visualisation of the fundus. A pterygium in this study is the wing shaped (triangular) growth of fibrovascular tissue which invades the cornea while a pingueclum is a small elevated yellow mass of fibrovascular tissue confined to the limbus and bulbar conjunctiva without any corneal involvement.

The data were analysed using INSTAT statistical package. Prevalence rate was calculated using the number of motorcyclists. Associations were evaluated using $X^{2}$ and unpaired t-test, Fishers exact test and multivariate analysis. P-value $<0.05$ was considered to be statistically significant.

\section{RESULTS}

A total of 144 motorcyclists, who were all males were involved in the study. The age range of the motorcyclists was 18 to 65 years with a mean age of $34.9 \pm 8.0(\mathrm{SD})$ years. Table 1 shows the age groups of the motorcyclists, $53(36.8 \%)$ were in the age group 21 to 30 years, while 59 (41\%) were between 31 to 40 years. There was only one person in the age group 10 to 20 years.

Table 1

Age distribution of motorcyclists

\begin{tabular}{lcc}
\hline Age (years) & Frequency & $(\%)$ \\
\hline $10-20$ & 1 & 0.7 \\
$21-30$ & 53 & 36.8 \\
$31-40$ & 59 & 41.0 \\
$41-50$ & 25 & 17.4 \\
$51-60$ & 5 & 3.5 \\
$>61$ & 1 & 0.7 \\
\hline Total & 144 & 100 \\
\hline
\end{tabular}

Pterygium was present in 18 patients. There were 12 bilateral cases making a total of 30 eyes. The prevalence of pterygium was $12.5 \%$ (95\% CI, 8 to 19). The age range of the patients with pterygium was 32 to 52 years with a mean age of $40.94 \pm 6.0$ (SD) years.

The total number of motorcyclists with pingueculae was 37 , while there were 26 bilateral cases and the total number of eyes was 63 . The prevalence of pingueculum was $25.7 \%$. The age 
range of the patients with pingueculum was 18 to 54 years with a mean age of $35.4 \pm 8.3(\mathrm{SD})$ years. There was no statistically significant difference between the ages of those with pterygium and those with pingueculum.

Table 2 shows the age groups of the indoor workers (control group). The age range of the control group was 19 to 57 years with a mean age of $34.7 \pm$ 9 (SD) years. There was no statistically significant difference in age between the motorcyclists and the control group.

Table 2

Age distribution of controls

\begin{tabular}{lcc}
\hline Age (years) & Frequency & $(\%)$ \\
\hline $10-20$ & 1 & 0.9 \\
$21-30$ & 35 & 30.7 \\
$31-40$ & 33 & 28.95 \\
$41-50$ & 33 & 28.95 \\
$51-60$ & 12 & 10.5 \\
\hline Total & 144 & 100 \\
\hline
\end{tabular}

The total number of eyes with pterygium in the control group was 12 in 9 persons making the prevalence rate of $7.9 \%$ (95\% CI, 3.0 to 12$)$. The number of people in the control group with pingueculum was 24 , while 46 eyes had pingueculum. There were some bilateral cases. The prevalence rate was $21.05 \%$ ( $5 \% \mathrm{CI}, 12$ to 28 ).

The age range of the motorcyclists without any eye lesion was 23 to 65 years with a mean age of 33.5 \pm 7.8 years (SD). There was no statistically difference between the ages of the motororcyclists without any lesion and those with pterygium or pingueculum, $p>0.05$.

The duration of work as a motorcyclist ranged from 1 to 14 years with a mean of $4.5 \pm 3.1$ years (SD) in those with pingueculum, while the range was 2 to 11 years with a mean of $5.2 \pm 3.6(\mathrm{SD})$ years for motorcyclists with pterygium. The range was 0.5 to 24 years with a mean of $4.8 \pm 3.1$ (SD) years for the motorcyclists without any lesion. The mean duration of work for motorcyclists with eye lesion (pingueculum or pterygium) was $4.5 \pm 3.1$ (SD) years. There was no statistically significant difference in the duration (length of time as a motorcyclist) between the groups, those with eye lesion and those without any lesion.
Tables 3 and 4 show the number of motorcyclists in the different groups (those with eye lesions or no lesion) who use caps/hats at work and those who do not use caps/hats. There were $121(84 \%)$ motorcyclists using caps while $23(16 \%)$ did not use caps at work. There was a statistically significant difference between the motorcyclists who wear caps/hats and those who do not wear caps/hats and the presence of pingueculum $(p=0.048)$. The wearing of caps !hats alone was not associated with the presence of pterygium ( $p>0.05$ ).

Table 3

Use of hats/caps among motocyclists

\begin{tabular}{lccccccc}
\hline Pingueculum & Yes & $(\%)$ & \multicolumn{2}{c}{ No } & $(\%)$ & \multicolumn{2}{c}{ Total (\%) } \\
\hline Present & 27 & 25.5 & 10 & 50 & 37 & 29.4 \\
Absent & 79 & 74.5 & 10 & 50 & 89 & 70.6 \\
\hline Total & 106 & 100 & 20 & 100 & 126 & 100 \\
\hline P-value $=0.029$ & & & & & & &
\end{tabular}

Table 4

\begin{tabular}{lccc}
\hline Pterygium & Yes & No & Total \\
\hline Present & 15 & 3 & 18 \\
Absent & 79 & 10 & 89 \\
\hline Total & 94 & 13 & 107 \\
\hline
\end{tabular}

P-value $=0.3789$

Tables 5 and 6 show the number of motorcyclists who wear protective sunglasses. Ninety $(62.5 \%)$ motorcyclists wear protective sunglasses while 54 (37.5\%) do not wear any protective sunglasses. There was no statistically significant difference between the two groups and thus there was no association between the use of sunglasses alone and prevalence of pterygium or pingueculum.

Table 5

Use of protective glasses among commercial motorcylists

\begin{tabular}{lccc}
\hline Pingueculum & Yes & No & Total \\
\hline Present & 21 & 16 & 37 \\
Absent & 60 & 29 & 89 \\
\hline Total & 81 & 45 & 126 \\
\hline
\end{tabular}

$\mathrm{P}$-value $=0.3086$ 
Table 6

\begin{tabular}{lccc}
\multicolumn{4}{c}{ Use of glasses } \\
\hline Pterygium & Yes & No & Total \\
\hline Present & 9 & 9 & 18 \\
Absent & 60 & 29 & 89 \\
\hline Total & 69 & 38 & 107 \\
\hline
\end{tabular}

$\mathrm{P}$-value $=0.1832$

Multivariate analysis showed a significant association and a protective effect between the wearing of caps/hats and glasses together and the development of pingueculum or pterygium $(p<0.01)$. The wearing of caps and glasses together was found to protect these motor cyclists from the development of pterygium or pingueculum.

\section{DISCUSSION}

A close relationship exists between pterygium and pingueculum. A pterygium may be derived from a pingueculum $(7,10,11)$. Austin et al (12) concluded that a large component of pingueculae and pterygia is the result of newly synthesised elastic fibre precursors and abnormal maturational forms of elastic fibres that undergo secondary degeneration and these structures are presumed to be elaborated by actinically damaged fibroblasts of the substantia propia. These facts strongly suggest that pterygium and pingueculae are causally related to prolonged actinic damage. Pterygium tissues show evidence of ultraviolet B induced p53 mutations in limbal epithelial tissues (5).

Cameron (4) noted that pterygium rates were higher in countries that were hot and dusty, and between 37 degrees north and south of the equator. The prevalence rate varies from $22.5 \%$ in Aruba, $8 \%$ in Puerto Rico (latitude 18 degrees) to $2 \%$ or less beyond the $40^{\text {th }}$ parallel (13). In Nigeria, the prevalence rate of pterygium has been found to vary from $9 \%$ in Ibadan, $4 \%$ in Eastern Nigeria to $0.8 \%$ in Benin City (14-16). These studies were all hospital based. The high rate found in Ibadan may be due to the fact that $65 \%$ of the patients were outdoor workers (14). The prevalence rates of $12.5 \%$ for pterygium and $25.7 \%$ for pingueculum found in commercial motorcyclists in Benin City are quite high compared to the other studies in Nigeria (14-16) but lower than that of
$37.7 \%$ for pinguculae in Police motorcyclists in India (17). The prevalence rates of $7.9 \%$ for pterygium and $21.05 \%$ for pingueculum in the control group (indoor workers) in this study are lower than the rates for the motor cyclists, thus suggesting that the motorcyclists are more at risk of developing these lesions as a result of their exposure to ultraviolet $B$ radiation, dusts and wind.

McCarthy et al (18) in their study in Australia found male sex, age, rural residence and lifetime ocular sun exposure or ultraviolet $B$ radiation to be important risk factors in the development of pterygium. All the motorcyclists in this present study were males, thus it is not surprising that the prevalence rate is high.

The prevalence of pterygium increases with age (7). Osahon et al (16) in their study in Benin City found the peak prevalence rate to be in the age group 31-40 years. The fact that $36.8 \%$ and $41 \%$ of the motorcyclists in this present study were in the age groups $21-$ 30 years and $31-40$ years respectively may have contributed to the high prevalence rate. Although there was no statistically significant difference in ages of the motorcyclists in the different groups, the mean age of those with pterygium was higher than the mean age for the other groups. Mackenzie et al (19) found that the risk of pterygium was increased in patients who in their 3rd decade of life work outdoors in an environment with high surface reflectance compared with those who work indoors, thus the high prevalence rate of pterygium in this present study is not surprising as most of the motorcyclists were in their 3rd and 4th decade of life.

Although there was no statistically significant difference in the mean duration of work between motorcyclists with pingueculum and pterygium and those without any eye lesion, it is still important to note that the major environmental risk factor for development of pterygium and pingueculum is exposure to UVB light $(6,17-21)$. These motorcyclists are continuously exposed to dust and ultraviolet $B$ radiation for long periods and thus are at risk of developing pingueculae and pterygia. Microtrauma from particulate material such as smoke or sand may contribute to the development of pterygium (6). The motorcyclists in this study work mainly in sandy environment and it has been found that working in a mainly sandy environment by ages 20 to 29 years increases the risk of developing pterygium by nearly 11 times (19). 
The prevalence rate of pingueculae was found to be higher among motorcycle policemen 590/1566 eyes $(37.7 \%)$ compared to $127 / 1414$ eyes $(30.6 \%)$ among indoor workers (17). Mackenzie et al's (19) study on the risk factors in the development of pterygium suggests a strong causal relationship exposure to ultraviolet light in the early years of life and a cumulative exposure over the next two or three decades in occupations where reflected ultraviolet light has also been found to be important in the development of pterygium (18).

Certain occupations with higher exposure to ultraviolet $B$ radiation have been shown to have higher prevalence of pterygium and pingueculae $(22,23)$. Pterygium was also associated with certain outdoor occupations such as stockmen, labourers, stationhands in the aboriginal population (3).

Persons wearing spectacles made of plastic or glass appear to be relatively protected from developing pterygium due to the blocking of ultraviolet radiation by these materials (19). The wearing of glasses or protective goggles and caps/hats together was found to protect these motorcyclists from developing pingueculum or pterygium in this study, thus they should be educated about the importance of wearing them together at work.

The usage of facecaps or brimmed hats by motorcyclists in this study was found to protect them from developing pingueculum. It is quite encouraging to note that a large number of the motorcyclists in this study wore caps/ hats as these have been shown to protect the eyes from the full exposure to ultraviolet radiation and reduce the risk of developing pterygium (19).

In conclusion, people who work outdoors are subjected to involuntary ultraviolet $B$ exposure. The highest exposure will occur during the two hours either side of noon. Workers must be made aware of this and they should take appropriate precautions. The presence of a brimmed hat has been found to reduce the face exposure to ultraviolet light by a factor of at least two and the eye exposure by a factor of four to five (2426). The prevalence rates of both pingueculum and pterygium in commercial motorcyclists in Benin City in this study are quite high when compared with those of indoor workers, thus there is a need for them to be educated about the importance of protecting their eyes from excessive exposure to sunlight by wearing face caps or hats and protective glasses.

\section{REFERENCES}

1. Dohn P.J. and Johnson G.J. Solar radiation and ocular disease: A review of epidemiological and experimental evidence. Ophthalmic. Epidemiol. 1994; 1: 155-164.

2. WHO. Environmental Health Criteria 160: Ultraviolet radiation. Geneva, 1994; pp 181-207.

3. Taylor H.R. Climatic droplet keratopathy and pterygium. Aust. J. Ophthalmol. 1981; 9: 199-206.

4. Cameron M.E. Pterygium throughout the world. Springfield 111. Charles C. Thomas 1965.

5. Dushku N. and Reid T.W. P53 expression in altered limbal basal cells of pingueculae, ptergia and limbal tumours. Curr. Eye Res. 1997; 16: 1179-1192.

6. Coroneo M.T. Pterygium as an early indicator of ultraviolet insolation: A hypothesis. Brit.J. Ophthalmol. 1993; 77: 734-739.

7. Hill J.C. and Maske R. Pathogenesis of pterygium. Eye. 1989; 2: 218-226.

8. Saw Seang-Mei and Tan D. Pterygium: Prevalence, demography and risk factors. Ophthalmic Epidemiol. 1999; 6: 219-228.

9. Araoye M.O. Research methodology with statistics for health and social sciences. $1^{\text {st }} \mathrm{ed}$. Ilorin, Nathadex Publishers. 2003; pp 115-129.

10. Jaros P.A. and Deluise V.P. Pinguculae and Pterygia. Suro. Ophthalmol. 1988; 33: 41-49.

11. Archila E.A. and Arenas M.C. Etiopathology of Pinguecula and Pterygium. Cornea. 1995; 14: 543-544.

12. Austin P., Jakobiec F.A. and Iwanoto I. Elastodysplasia and elastodystrophy in the pathologic bases of ocular pterygia and pingueculae. Ophthalmol. 1983; 90: 96-109.

13. Townsend W.M. Pterygium. In: Kaufman H.E., Barron B.A., McDonald M.B. and Waltman S.R., eds. The Cornea. $1^{\text {st }}$ edn. New York: Churchill Livingstone, 1988; pp 461-483.

14. Ashaye A.O. Pterygium in Ibadan. West Afr. J. Med. 1991; 10: 232-243.

15. Nworah P.B. Prevalence of Pterygium in Enugu, Nigeria. Nigeria J. Opththalmol. 1986; 2: 94-98.

16. Osahon A.I. and Edema O.T. Pterygium in Benin City, Nigeria. A hospital based study. Nigeria J. Surg. 1998; 5: 77-80.

17. Nakaishi H., Yamamoto M., Ishide M., Someya J. and Yamada Y. Pingueculae and Pterygia in motorcycle policemen. Ind. Hlth. 1997; 35: 325-329.

18. McCarty C.A., Fu C.L. and Taylor H.R. Epidemiology of pterygium in Victoria, Australia. Brit. J. Ophthalmol. 2000; 84: 289-292. 
19. Mackenzie F.D., Hirst L.W., Battistutta D. and Green A. Risk analysis in the development of pterygia. Ophthalmol. 1992; 99: 1056-1061.

20. Taylor H., West S., Munoz B., Rosenthal F., Bressler S. and Bressler $N$. The long-term effects of visible light on the eye. Arch. Ophthalmol. 1992; 110: 99-104.

21. Lim R., Mitchell P. and Cumming R.G. Cataract associations with pinguecula and pterygium: The Blue Mountain Eye Study. Amer. J. Ophthalmol. 1998; 126: 717-719.

22. Karai I. and Horiguchi S. Pterygium in welders. Brit. J. Ophthalmol. $1984 ; 68: 347-349$.
23. Norn M. and Franck C. Long-term changes in the outer part of the eye in welders. Acta. Ophthalmol. 1991; 69: 382-386.

24. Diffey B.L., Tate T.T. and Davis A. Solar dorsimetry of the face: The relationship of naural ultraviolet exposure to basal cell carcinoma locaton. Phys. Med. Boil. 1979; 24: 931-939.

25. Diffey B.L. and Cheeseman J.Sun protection with hats. Brit. J. Dermatol. 1992; 127: 10-12.

26. Roy C.R., Gies H.P. and Elliot G. Solar ultraviolet radiation: Personnel exposure and protection. J. Occup. Health(Aust NZ). 1988; 4: 133. 